\title{
MDM2 wt Allele
}

National Cancer Institute

\section{Source}

National Cancer Institute. MDM2 wt Allele. NCI Thesaurus. Code C51283.

Human MDM2 wild-type allele is located within 12q14.3-q15 and is approximately $32 \mathrm{~kb}$ in length. This allele, which encodes E3 ubiquitin-protein ligase Mdm2 protein, plays a role in the regulation of transactivation by tumor protein p53, as part of an autoregulatory negative feedback loop. Overexpression of MDM2 can result in excessive inactivation of tumor protein p53 and diminish its tumor suppressor capability. 